\title{
A Thermodynamic Analysis of an Air-Cooled Proton Exchange Membrane Fuel Cell Operated in Different Climate Regions
}

\author{
Torsten Berning * ${ }^{*}$ and Søren Knudsen Kær(D) \\ Department of Energy Technology, Aalborg University, 9100 Aalborg, Denmark; skk@et.aau.dk \\ * Correspondence: tbe@et.aau.dk
}

Received: 23 April 2020; Accepted: 18 May 2020; Published: 20 May 2020

\begin{abstract}
A fundamental thermodynamic analysis of an air-cooled fuel cell, where the reactant air stream is also the coolant stream, is presented. The adiabatic cell temperature of such a fuel cell is calculated in a similar way as the adiabatic flame temperature in a combustion process. Diagrams that show the dependency of the cathode outlet temperature, the stoichiometric flow ratio and the operating cell voltage are developed. These diagrams can help fuel cell manufacturers to identify a suitable blower and a suitable operating regime for their fuel cell stacks. It is found that for standard conditions, reasonable cell temperatures are obtained for cathode stoichiometric flow ratios of $\xi=50$ and higher, which is in very good agreement with manufacturer's recommendations. Under very cold ambient conditions, the suggested stoichiometric flow ratio is only in the range of $\xi=20$ in order to obtain a useful fuel cell operating temperature. The outside relative humidity only plays a role at ambient temperatures above $40^{\circ} \mathrm{C}$, and the predicted stoichiometric flow ratios should be above $\xi=70$ in this region. From a thermodynamic perspective, it is suggested that the adiabatic outlet temperature is a suitable definition of the fuel cell operating temperature.
\end{abstract}

Keywords: air-cooled proton exchange membrane fuel cells; adiabatic fuel cell temperature; thermodynamic analysis of proton exchange membrane fuel cells

\section{Introduction}

Air-cooled, low-temperature proton exchange membrane fuel cells (PEMFCs) are attractive for applications in the range of up to a few $\mathrm{kW}$. Among the salient features is their simplicity of operation because they do not need a secondary coolant loop. The major disadvantage is the relatively low observed maximum current density of around $0.3-0.4 \mathrm{~A} / \mathrm{cm}^{2}$, which severely limits the power density [1]. Moreover, it is often difficult to operate these fuel cells in extreme climate conditions.

The principle of air-cooled fuel cells is the same as of liquid-cooled fuel cells: oxygen from air is combined with hydrogen to produce water and electricity. A certain amount of waste heat is produced due to overpotentials that predominantly occur at the fuel cell catalysts and inside the proton conductive membrane. The half-cell reactions are:

$$
\begin{array}{lll}
\text { Anode: } & \mathrm{H}_{2} & \Rightarrow 2 \mathrm{H}^{+}+2 e^{-} \\
\text {Cathode: } & \frac{1}{2} \mathrm{O}_{2}+2 \mathrm{H}^{+}+2 e^{-} & \Rightarrow \mathrm{H}_{2} \mathrm{O} \\
\text { Combined: } & \mathrm{H}_{2}+\frac{1}{2} \mathrm{O}_{2} & \Rightarrow \mathrm{H}_{2} \mathrm{O}
\end{array}
$$

The electrons produced by the anode half-cell reaction are driven through an external circuit to the cathode by the electro-motive force, and the protons migrate through the polymer electrolyte membrane, which is proton conductive and electron repellant. In order to have the reactions occurring at an appreciable rate, overpotentials have to be applied, and these are the sources of waste heat. 
While the theoretical cell potential between anode and cathode based on thermodynamics should be $1.23 \mathrm{~V}$, practical operating voltages are $0.5-0.8 \mathrm{~V}$. In order to obtain an appreciable voltage, numerous single fuel cells are combined in a fuel cell stack, where the stack voltage is the sum of the individual cell voltages and the current that is drawn through all cells in series. A simple schematic of a fuel cell is shown in Figure 1.

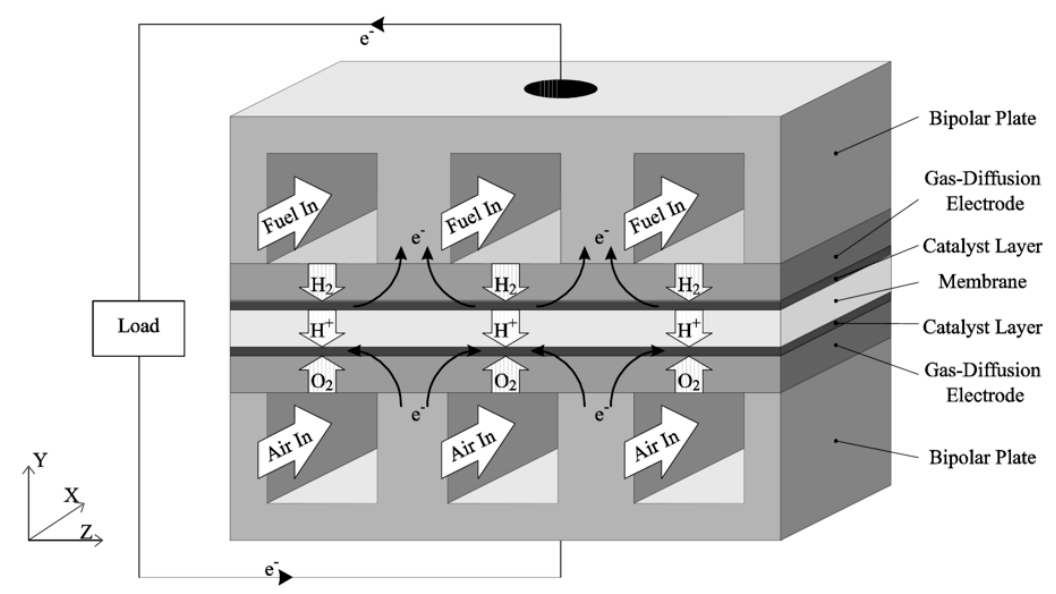

Figure 1. Proton exchange membrane fuel cell (PEMFC) schematic [2].

The thermo-neutral potential of the fuel cell reaction is $1.482 \mathrm{~V}$, assuming that the product water is in the liquid phase [3]. The corresponding potential based on the lower heating values is $1.254 \mathrm{~V}$ [3]. The difference between the thermo-neutral potential and the fuel cell operating voltage multiplied with the fuel cell current density is the amount of waste heat that is produced inside the fuel cell, and the fuel cell efficiency is directly proportional to the fuel cell voltage.

In air-cooled, low-temperature PEMFCs, the waste heat is removed by excessive air that is being fed to the fuel cell. Therefore, the reactant air is, at the same time, the coolant air, and the stoichiometric flow ratio, $\xi$, must be high. Such units are already widely commercially available, a leading manufacturer being Ballard Power Systems [4].

One of the disadvantages of air-cooled PEMFCs is their low maximum current density of only around $0.4 \mathrm{~A} / \mathrm{cm}^{2}$ (e.g., References [5,6]), which severely limits the power density. By comparison, liquid-cooled PEMFCs that are being developed for automotive applications have a maximum current density of up to $2.0 \mathrm{~A} / \mathrm{cm}^{2}$, which lead to power densities in the range of $1.0 \mathrm{~W} / \mathrm{cm}^{2}$. It should be a goal to increase the maximum current density that can be drawn from an air-cooled fuel cell because this will lead to a substantial increase in their power density. It is clear that such an increase in power density also leads to a cost reduction.

Since the reactant air is directly taken from the environment, the performance and thermal management of these fuel cells is very sensitive to the ambient conditions. While it is no problem to operate such a fuel cell stack at an ambient temperature of $25^{\circ} \mathrm{C}$ and typical relative humidity levels for temperate climate regions, the air-cooled fuel cell operation becomes less stable in regions with extreme temperatures. These systems are also placed in remote regions with extreme climates, and stable operation must be ensured. Thus, there is a need to fundamentally understand the impact of the ambient temperature on the expected performance or even the possibility to operate such a stack at extreme conditions.

Figure 2 summarizes suitable operating ranges as identified experimentally by Ballard Power Systems [4]. The nominal power density at standard conditions is around $0.225 \mathrm{~W} / \mathrm{cm}^{2}$ and the maximum current density is around $0.4 \mathrm{~A} / \mathrm{cm}^{2}$ [4]. Depending on the outside conditions, the cathode stoichiometric flow ratio is typically in the region $\xi_{c a}=50-120$, and the stack performance was observed to become unstable below a cathode side stoichiometric flow ratio of $\xi_{c a}=20$. The ambient relative humidity has a stronger effect at temperatures higher than $40^{\circ} \mathrm{C}$, and the effect on the performance 
is stronger in very dry regions. On the anode side, the stoichiometric flow ratio must be as low as possible in order to preserve the hydrogen, and in practice, stacks are operated below an anode side stoichiometry of $\xi_{\text {an }}=1.1[4]$.

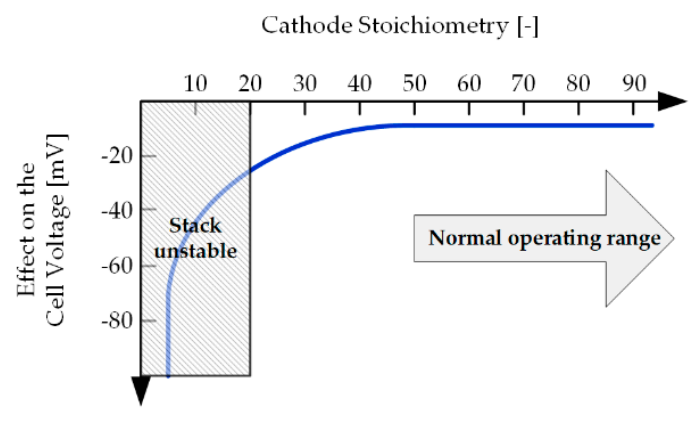

(a)

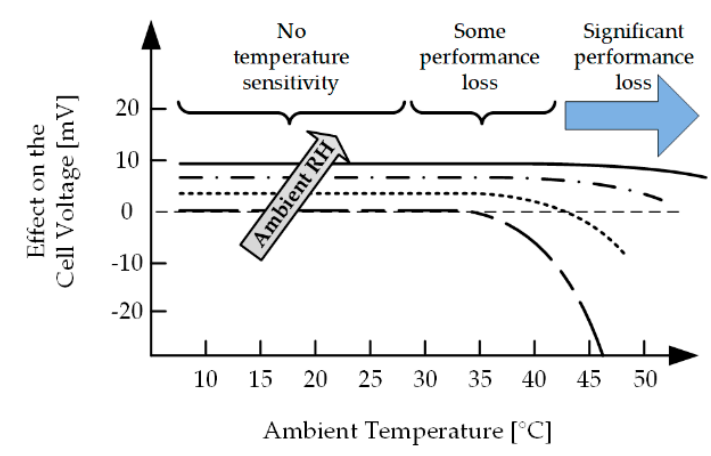

(b)

Figure 2. Effect of (a) the stoichiometric flow ratio and (b) of the ambient relative humidity and temperature on the performance of an air-cooled fuel cell stack. Adapted from Reference [4] with permission from Ballard Power Systems, January 2019.

Over the past decade, air-cooled fuel cells have been studied by several research groups. An important distinction to make is between (i) air-breathing fuel cells that rely on natural convection to provide the reactant air and which can be used for power ranges up to $100 \mathrm{~W}$, and (ii) air-cooled fuel cells, where the reactant air is provided by a fan or compressor which necessitates work and increases the system complexity [7]. The latter are being considered for remote power supply, such as telecom back-up, and they operate in power ranges of up to a few $\mathrm{kW}$. Because the reactant air is directly taken from and removed to the environment, this type of fuel cell is also termed an open cathode fuel cell.

Jeong et al. [8] conducted experiments on air-breathing fuel cells in a climate chamber where the operating conditions were varied. The recorded maximum current density was $0.4 \mathrm{~A} / \mathrm{cm}^{2}$, and the power density was below $0.2 \mathrm{~W} / \mathrm{cm}^{2}$. The anode was operated on dry hydrogen, and the water balance of the cell was measured by placing a water-absorbing material in the anode outlet and weighing the amount of water that has accumulated over a certain amount of time. The recorded water balance results were in very good agreement with our own experiments [9].

Publications of experimental studies on an existing commercial stack included Zhu et al. [5], Del Real et al. [6] and Adzakpa et al. [10]. All these groups reported current densities below $0.4 \mathrm{~A} / \mathrm{cm}^{2}$.

The publication by Wu et al. [11] included a detailed literature study, and this group conducted experiments on a single cell and a stack that consisted of 5 cells. The cells were operated on humidified hydrogen at $55^{\circ} \mathrm{C}$ at the anode and dry, ambient air at the cathode. The observed maximum current density for the single fuel cell experiments was around $0.3 \mathrm{~A} / \mathrm{cm}^{2}$, and in case of the stack, it was below $0.25 \mathrm{~A} / \mathrm{cm}^{2}$. There was no additional heating or cooling in the end plates and the results showed that the center temperature was $8^{\circ} \mathrm{C}$ higher than the outer cells near the end plates.

Beside these experimental research efforts, several groups have conducted modeling studies to better understand heat and mass transfer in air-cooled PEMFCs. Sasmito et al. [12-15] published several computational fluid dynamics studies that included the predicted cell performance using the commercial software ANSYS Fluent. In Reference [12], this group investigated the placement of the fan and the effect of the channel height on the predicted performance and pressure drop. One finding was that the height of the cathode channels had a strong impact on the maximum current density, which was slightly above $0.3 \mathrm{~A} / \mathrm{cm}^{2}$. In Reference [13], this group compared the performance of the cell for a natural convection stack and a forced convection stack, where the fan was placed before the stack and the fan power was varied. For forced convection, the maximum current density was $0.35 \mathrm{~A} / \mathrm{cm}^{2}$ before the stack was overheated, while it was below $0.2 \mathrm{~A} / \mathrm{cm}^{2}$ for natural convection. A novel flow reversal concept was then proposed by the same group in Reference [14], where a fan was placed before 
and behind the stack and flow shifting was introduced with the goal of preventing stack overheating. While the model predicted a temperature reversal according to the periodicity of the flow shifting, no performance improvement was indicated. However, this concept helped to reduce the temperature gradients and better understand the frequency of the flow reversal. Finally, the selection of the fan based on different fan types with different performance curves was studied in Reference [15].

Shahsavari et al. [16] and Akbari et al. [17] developed a single-phase computational model of an air-cooled fuel cell using COMSOL Multiphysics ${ }^{\circledR}$. The focus was put on a better understanding of the thermal management and the prediction of the maximum stack temperature as well as the main temperature gradient, which occurs in the flow direction. They simulated a commercial fuel cell stack by Ballard Power Systems and obtained very good agreement between their modeling predictions and the measured maximum temperature. Unfortunately, performance data or maximum current densities obtainable from that fuel cell stack were not released.

Other, very interesting work on air-cooled fuel cells was published by Meyer et al. [18,19]. Their studies focused on a commercial fuel cell design by Intelligent Energy, and the fuel cells differ from the above-listed stacks in that air is used as a coolant in separate cooling channels. The reactant air is fed in flow channels at a low stoichiometry. These air-cooled fuel cells are consequently more similar to liquid-cooled fuel cells, which was also pointed out by Sasmito et al. [13].

More work on air-cooled fuel cell stacks that have separate cooling channels include the study by Chen et al. [20], who developed a high-power air-cooled fuel cell stack with a current density above $0.8 \mathrm{~A} / \mathrm{cm}^{2}$. The resulting power density was an impressive $0.6 \mathrm{~W} / \mathrm{cm}^{2}$, and the stoichiometric flow ratio of the reactant air was only 1.5-2.0 and below. However, the cooling channels accounted for $55 \%$ of the bipolar plates' frontal area, which also means that the membrane-electrode-assembly had to be larger compared to, e.g., a Ballard stack. The active area of that stack was roughly $113 \mathrm{~cm}^{2}$ and the maximum current was $100 \mathrm{~A}$. The resulting power output was $2.55 \mathrm{~kW}$.

Finally, a very good overview of the different cooling strategies in PEMFC stacks was given by Zhang and Kandlikar [21], while Flückiger et al. [22] conducted a thermal modeling analysis of an air-cooled fuel cell stack with edge cooling.

Air-cooled fuel cells are often used as telecom back-up applications in regions with extreme climates. In order to understand, under which conditions such fuel cells may operate, a thermodynamic analysis based on the first law of thermodynamics is conducted in this work. The calculations presented here are inspired by the calculation of the adiabatic flame temperature in a combustion process, and it will be shown that the outlet temperature of the reactant gases depend only on the ambient conditions, the stoichiometric flow ratio of the cathode air (the anode side stoichiometry is fixed to a low value) and the operating cell voltage. The latter determines the amount of waste heat that has to be removed predominantly by the excess air. In doing so, feasible operating regimes for these air-cooled fuel cells are identified and compared to the empirically determined regimes by Ballard Power Systems.

The main motivation for the current study is therefore:

- A lack of fundamental understanding concerning the required amount of air to control the fuel cell temperature, i.e., the stoichiometric flow ratio.

- A lack of fundamental understanding of how the ambient conditions affect the required air flow rates, and under what conditions it is feasible to operate such a fuel cell stack without a preheater.

- A lack of fundamental understanding of which blower has to be paired with such an air-cooled fuel cell stack under various ambient conditions.

\section{Formulation of the Molar Flow Rates and the Energy Balance}

\subsection{Assumptions}

The analysis carried out below is conducted in a similar way as the calculation of the adiabatic flame temperature in a combustion process by applying the first law of thermodynamics. It is based on 
assuming ideal gas behavior, and changes in potential and kinetic energy are neglected. Moreover, the calculations assume steady-state operation.

\subsection{Thermodynamic System Considered}

The system under consideration is shown in Figure 3. It is the goal to determine the adiabatic outlet temperature of the reactant gases, so all the waste heat is carried out of the cell in the form of internal heat and the temperature of the product gases is increased. In contrast to the calculation of the adiabatic flame temperature in a combustion process, the electrical work performed by the fuel cell has to be accounted for because it is clear that the adiabatic outlet temperature of a fuel cell depends strongly on the cell performance. For simplicity, it is assumed that anode and cathode gas streams enter and leave the cell at the same temperature. Under such conditions, the exact water balance of the fuel cell plays no role, i.e., it does not matter whether the product water leaves from the cathode side or anode side because the water vapor leaves the cell at the same temperature.

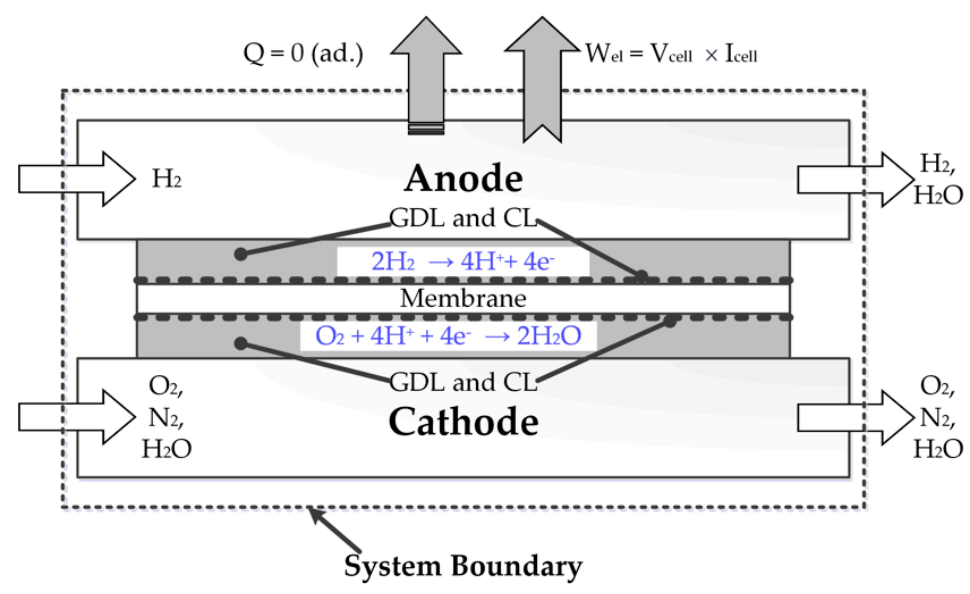

Figure 3. System boundary for the first-law analysis.

\subsection{Molar Inlet Streams}

In order to conduct a first-law analysis of an air-cooled system, the molar flow rates have to be formulated before the enthalpy streams are calculated. This has already been done in numerous previous articles in PEMFC (e.g., Reference [23]). The incoming molar stream of oxygen depends on the cathode stoichiometric flow ratio, $\xi_{c a}$, and the total current that is drawn from the fuel cell stack, I:

$$
\dot{n}_{\mathrm{O}_{2}, i n}=\xi_{c a} \frac{I}{4 F}
$$

where $F$ is Faraday's constant $(96,485 \mathrm{C} /$ mole). Note that the total current is not the physical current drawn from the fuel cell stack in experiments, but the physical current drawn from each cell multiplied with the number of cells in the stack.

On a molar basis, the incoming amount of nitrogen is:

$$
\dot{n}_{N_{2}, \text { in }}=\frac{79}{21} \dot{n}_{\mathrm{O}_{2}, \text { in }}=\frac{79}{21} \times \xi_{c a} \times \frac{I}{4 F}
$$

There is a certain amount of water vapor entering the cell that depends on the relative humidity of the ambient air, $R H_{\text {in }}$, which is introduced as a free parameter:

$$
R H_{\text {in }}=\frac{p_{\mathrm{H}_{2} \mathrm{O}}}{p_{\text {sat }}(T)}=x_{\mathrm{H}_{2} \mathrm{O}} \frac{p_{\text {amb }}}{p_{\text {sat }}(T)}=\frac{\dot{n}_{\mathrm{H}_{2} \mathrm{O}, \text { in }}}{\dot{n}_{\text {tot, in }}} \frac{p_{\text {amb }}}{p_{\text {sat }}(T)}
$$


From this, it follows that:

$$
\dot{n}_{\mathrm{H}_{2} \mathrm{O}, \text { in }}=R H_{\text {in }} \times \frac{p_{\text {sat }}(T)}{p_{a m b}} \times \dot{n}_{\text {tot, }, \text { in }}=R H_{\text {in }} \times \frac{p_{\text {sat }}(T)}{p_{a m b}} \times\left(\dot{n}_{\mathrm{H}_{2} \mathrm{O}, \text { in }}+\dot{n}_{\mathrm{O}_{2}, \text { in }}+\dot{n}_{\mathrm{N}_{2}, \text { in }}\right)
$$

which results in:

$$
\dot{n}_{\mathrm{H}_{2} \mathrm{O}, \text { in }}=R H_{\text {in }} \times\left(\frac{p_{\text {amb }}}{p_{\text {sat }}(T)}-R H_{\text {in }}\right)^{-1} \times\left(\dot{n}_{\mathrm{O}_{2}, \text { in }}+\dot{n}_{\mathrm{N}_{2}, \text { in }}\right)
$$

It is desirable to express the amount of water entering the cell as a function of the current and the stoichiometry, similar to the oxygen and nitrogen stream. Inserting Equations (1) and (2) and reformulation yields:

$$
\dot{n}_{H_{2} \mathrm{O}, \text { in }}=R H_{\text {in }} \times\left(\frac{p_{\text {amb }}}{p_{\text {sat }}(T)}-R H_{\text {in }}\right)^{-1} \times \frac{1}{0.21} \times \xi_{\text {ca }} \frac{I}{4 F}
$$

The ratio between the water vapor flux and the incoming amount of oxygen is thus:

$$
\frac{\dot{n}_{\mathrm{H}_{2} \mathrm{O}, \mathrm{in}}}{\dot{n}_{\mathrm{O}_{2}, \text { in }}}=\frac{1}{0.21} \times R H_{\text {in }} \times\left(\frac{p_{\text {amb }}}{p_{\text {sat }}(T)}-R H_{\text {in }}\right)^{-1}
$$

The saturation pressure is only a function of the temperature and it can be conveniently expressed by Antoine's equation:

$$
p_{\text {sat }}(T)=D \times \exp \left(A-\frac{B}{C+T}\right)
$$

where $A=8.07131, B=1730.63, C=233.426$ and $D$ is introduced to convert from the unit $(\mathrm{mmHg})$ into $(\mathrm{Pa})$, and it is $133.233 . \mathrm{T}$ is the temperature given in ${ }^{\circ} \mathrm{C}$. For an ambient temperature of $25^{\circ} \mathrm{C}$, the saturation pressure is thus $3158 \mathrm{~Pa}$. Assuming an atmospheric total pressure, the molar flow rate of water vapor is, at a maximum $\left(R H_{\text {in }}=1\right), 15.3 \%$ that of oxygen.

At the anode side, dry hydrogen is assumed to enter the cell at a specified stoichiometric flow ratio:

$$
\dot{n}_{H_{2}, i n}=\xi_{\text {an }} \frac{I}{2 F}
$$

\subsection{Molar Outlet Streams}

For the molar stream of oxygen leaving the cell, it holds that:

$$
\dot{n}_{\mathrm{O}_{2}, \text { out }}=\left(\xi_{\mathrm{ca}}-1\right) \frac{I}{4 F}
$$

and the stream of the inert nitrogen is:

$$
\dot{n}_{N_{2}, \text { out }}=\dot{n}_{N_{2}, \text { in }}=\frac{79}{21} \times \xi_{\text {ca }} \times \frac{I}{4 F}
$$

The water at the outlet is the amount that has entered the cell plus the product water. In this case, the overall water balance of the fuel cell does not matter as both the anode and outlet stream are assumed to leave the cell at the same temperature. In case of doubt, it may be assumed that all of the product water leaves at the cathode side owing to the very low anode side stoichiometric flow ratio.

$$
\dot{n}_{\mathrm{H}_{2} \mathrm{O}, \text { out }}=\dot{n}_{\mathrm{H}_{2} \mathrm{O}, \text { in }}+\frac{I}{2 F}=R H \times\left(\frac{p_{\text {amb }}}{p_{\text {sat }}(T)}-R H\right)^{-1} \times \frac{1}{0.21} \times \xi_{\text {ca }} \frac{I}{4 F}+\frac{I}{2 F}
$$




\subsection{Formulation of the Energy Balance}

Applying the first law of thermodynamics to an air-cooled PEMFC according to Figure 3, it holds that:

$$
Q-W_{\text {el }}=H_{\text {prod }}-H_{\text {react }}
$$

here, $Q$ is the heat loss of the cell and $W_{e l}$ is the work that is extracted from the cell. In the current case, the system is considered adiabatic, $Q=0$, and $W_{e l}$ is expressed as:

$$
W_{e l}=V_{\text {cell }} \times I_{\text {cell }}
$$

Because the system is assumed to be adiabatic, the calculated temperature of the outlet gases is at a maximum. If the amount of heat loss from the stack to the surroundings is known, it may be entered here. The current analysis reveals no information about the temperature distribution inside the fuel cell stack, where the local temperature can be higher than the adiabatic outlet temperature of the reactant gases. Such a temperature distribution may be obtained by a detailed analysis, as carried out by Shahsavari et al. [16].

Assuming ideal gas behavior, the enthalpy streams can be calculated as follows:

$$
H=\sum \dot{n}_{i} h_{i}=\sum \dot{n}_{i}\left[h_{f}^{0}+\left(h-h^{0}\right)\right]=\sum \dot{n}_{i}\left[h_{f}^{0}+c_{p}\left(T-T^{0}\right)\right]
$$

where $h$ indicates molar enthalpies in $(\mathrm{J} / \mathrm{mol})$. The molar enthalpy of any species consists of two terms: the enthalpy of formation, $h_{f}^{0}$, at $25^{\circ} \mathrm{C}$ and $1 \mathrm{~atm}$ and the sensible enthalpy due to a temperature increase. The enthalpy of formation for stable elements like oxygen, nitrogen and hydrogen is zero, whereas the enthalpy of formation, $h_{f}^{0}$, of liquid water vapor is $-285,830 \mathrm{~J} / \mathrm{mol}$ and of water vapor is $-241,820 \mathrm{~J} / \mathrm{mol}[24]$.

For the calculation of the adiabatic gas outlet temperatures, the first law of thermodynamics thus reduces to:

$$
W_{e l}=\sum \dot{n}_{\text {prod }} h_{\text {prod }}-\sum \dot{n}_{\text {reac }} h_{\text {reac }}
$$

\begin{tabular}{|c|c|c|c|}
\hline Species & $\begin{array}{c}\mathrm{M} \\
(\mathrm{kg} / \mathrm{mol})\end{array}$ & $\begin{array}{c}c_{p} \\
(\mathrm{~J} / \mathrm{mol}-\mathrm{K})\end{array}$ & $\begin{array}{c}h^{0} \\
(\mathrm{~J} / \mathrm{mol})\end{array}$ \\
\hline Oxygen & 0.032 & 30.000 & 8682 \\
\hline Nitrogen & 0.028 & 29.484 & 8669 \\
\hline Hydrogen & 0.002 & 28.614 & 8468 \\
\hline Water Vapor & 0.018 & 33.462 & 9904 \\
\hline
\end{tabular}

The required properties are listed in Table 1.

Table 1. Gas properties at $298 \mathrm{~K}$ [24].

For demonstration purposes only, we assume the incoming gas stream of the air-cooled system to be at the standard conditions of $25^{\circ} \mathrm{C}$ and $1 \mathrm{~atm}$, so that the incoming enthalpy streams of oxygen, nitrogen and hydrogen are zero compared to the standard condition. Moreover, it is assumed for simplicity that the incoming air is completely dry so that there is no water vapor entering. Therefore, according to Equation (15), the incoming enthalpy stream is zero relative to the standard conditions. The outlet pressure of the fuel cell shall also be assumed to be $1 \mathrm{~atm}$.

Inserting the above expressions into the energy balance then results in:

$$
V_{\text {cell }} \times I_{\text {cell }}=\dot{n}_{\mathrm{O}_{2}, \text { out }}\left(h-h^{0}\right)_{\mathrm{O}_{2}}+\dot{n}_{\mathrm{N}_{2}, \text { out }}\left(h-h^{0}\right)+\dot{n}_{\mathrm{H}_{2}, \text { out }}\left(h-h^{0}\right)+\dot{n}_{\mathrm{H}_{2} \mathrm{O}, \text { out }}\left(h_{f}^{0}+h-h^{0}\right)
$$


The unit on both sides is in Watts, and it is observed that the enthalpy of formation is only considered for the water. So far, we have not decided whether the product water will be in gas or liquid phase. Obviously, the maximum cell temperature will be lower when the product water is in the gas phase, but it depends on the outlet temperature when the outlet gas phase will become saturated. Given the fact that these fuel cells operate on ambient air which is typically heated up inside the cell by $20-30{ }^{\circ} \mathrm{C}$ at a high stoichiometric flow ratio, it may be assumed that the product water leaves the cell in the vapor phase.

It is observed that, according to Equations (1), (2) and (5), the molar flow rates depend directly on the cell current, $I_{\text {cell }}$, which means that it can be canceled out in Equation (17). Inserting the molar flow rate and canceling yields:

$$
\begin{aligned}
V_{\text {cell }} & =\frac{1}{4 F} \times\left(\xi_{\text {ca }}-1\right) \times\left(h_{\mathrm{O}_{2}}\left(T_{\text {out }}\right)-8682 \frac{\mathrm{kJ}}{\mathrm{kmole}}\right) \\
& +\frac{1}{4 F} \times 3.762 \times \xi_{\text {ca }} \times\left(h_{\mathrm{N}_{2}}\left(T_{\text {out }}\right)-8669 \frac{\mathrm{kJ}}{\mathrm{kmole}}\right) \\
& +\frac{1}{2 F} \times\left(\xi_{\text {an }}-1\right) \times\left(h_{\mathrm{H}_{2}}\left(T_{\text {out }}\right)-8468 \frac{\mathrm{kJ}}{\mathrm{kmole}}\right) \\
& +\left[R H \times\left(\frac{p_{\text {amb }}}{p_{\text {sat }}(T)}-R H\right)^{-1} \times \frac{1}{0.21} \times \frac{\xi_{\text {ca }}}{4 F}+\frac{1}{2 F}\right] \\
& \times\left(-241,820 \frac{\mathrm{kJ}}{\mathrm{kmole}}+h_{\mathrm{H}_{2} \mathrm{O}}\left(T_{\text {out }}\right)-8468 \frac{\mathrm{kJ}}{\mathrm{kmole}}\right)
\end{aligned}
$$

From Equation (18), it follows that there are only four independent parameters in this analysis: the cell voltage, $V$, the stoichiometric flow ratio of the cathode side, $\xi_{C a}$, the outside relative humidity, $R H$, and the temperature of the outlet gases, $T_{\text {out }}$. This leaves aside the anode stoichiometric flow ratio, which should always be as close to unity as possible, which leads to the fact that the anode enthalpy stream is negligible. In combustion analysis, it is common to apply an iterative method to determine the temperature of the outlet gases. On the other hand, it is just as convenient to construct diagrams where the cell voltage is the $y$-axis and the adiabatic outlet temperature of the gases is the $x$-axis. With the anode stoichiometric flow ratio fixed at a low value of $\xi_{a n}=1.1$, and for a given ambient pressure and relative humidity, the cathode stoichiometric flow ratio is then the only free parameter left and a different value for $\xi_{c a}$ will give a different curve in the $V$ - $T_{a d}$-Diagram. Such diagrams can be constructed for different ambient conditions in which the fuel cell is placed, and these are shown and analyzed in the next section.

\section{A Thermodynamic Analysis of Air-Cooled PEM Fuel Cells Using $V-T_{a d}$-Diagrams}

The above equations can now be applied to study the adiabatic cell temperature, i.e., the temperature of the product gases assuming all the waste heat is carried out by the flew gases. To this end, the above equations can be entered into spreadsheet calculation software where the outlet temperature is the adjustable parameter. As can be seen from Equation (18), the relative difference between the inlet and outlet molar enthalpy streams can be given in terms of a voltage. This voltage depends only on the temperature of the outlet gases and the outside conditions. Besides the cell voltage, the cathode stoichiometric flow ratio is the most important parameter. Clearly, the ambient air temperature and the relative humidity have an impact on the adiabatic outlet temperature. In the following, four different cases will be examined in detail. In all cases, the ambient pressure was assumed to be 1 bar, but according to Equation (18), that property only plays a role in the calculation of the amount of water vapor that enters the cell.

\subsection{Case 1: Standard Conditions}

Standard operating conditions are that the inlet gas streams enter at $25^{\circ} \mathrm{C}$. It is assumed that the relative humidity of the ambient air was $30 \%$. Figure 4 shows the resulting dependency between the gas outlet temperature, the stoichiometric flow ratio and the cell voltage. All the lines have a 
negative slope because if the cell voltage decreases for a given stoichiometric flow ratio, more waste heat is produced and therefore, the cathode outlet temperature increases. The right-hand side of Figure 4 zooms in on the region of interest. The supplier of our fuel cell stack states that the stack outlet temperature should not exceed $60^{\circ} \mathrm{C}$ and the stack voltage should be below $0.9 \mathrm{~V}$ to avoid irreversible degradation [4]. On the other hand, the voltage should be above $0.6 \mathrm{~V}$, if possible, to ensure satisfactory cell performance. From this diagram, a working point under the given operating conditions may be read, e.g., a stoichiometry of 50 and a cell voltage of $0.7 \mathrm{~V}$. Under these conditions, the adiabatic outlet temperature of the reactants will be $50{ }^{\circ} \mathrm{C}$. Thus, the thermodynamic analysis yields a fundamental explanation of the preferred operating conditions, as specified by the manufacturer.

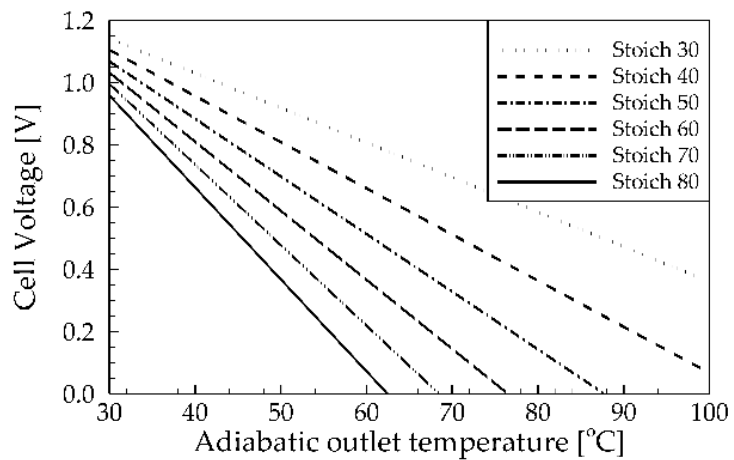

(a)

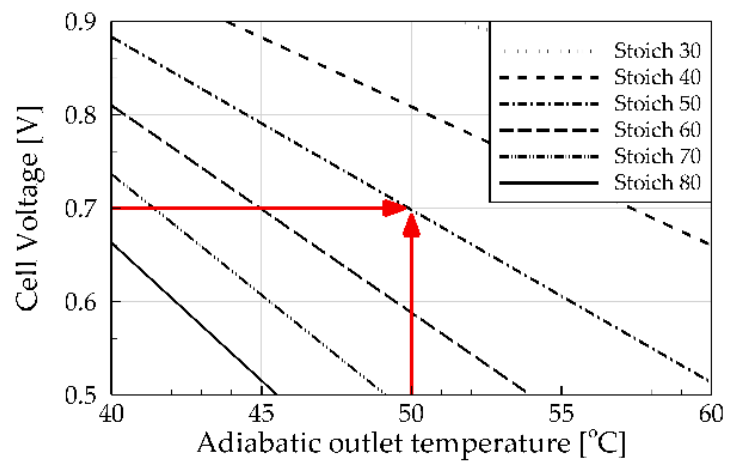

(b)

Figure 4. Dependency of the adiabatic outlet temperatures of the product stream on the operating cell voltage. The incoming conditions were a temperature of $25^{\circ} \mathrm{C}$ and a relative humidity of $30 \%$. (a) Entire voltage range, (b) close-up on the region of interest.

Varying the RH of the inlet air has only a very small impact on the results (not shown), and this is also in good agreement with Figure 2. It is interesting to note that when the cell potential drops from $0.7 \mathrm{~V}$ to $0.6 \mathrm{~V}$, the adiabatic outlet temperature increases by only $5{ }^{\circ} \mathrm{C}$ and it would even stay the same if the stoichiometric flow ratio would be increased from 50 to around 57. In practice, the fuel cell temperature is monitored in a position inside the cathode flow channel and adjusted by the fan drawing the air through the stack [4]. Overall, these diagrams suggest that there is no inherent reason why an air-cooled fuel cell should not be operational at high current densities.

\subsection{Case 2: Cold and Dry Conditions}

It is a requirement that fuel cell systems for telecom back-up applications also operate in an environment with a temperature as low as $-40{ }^{\circ} \mathrm{C}$. For the sake of demonstration, it is assumed that cold air at $-20^{\circ} \mathrm{C}$ is indeed fed to the fuel cell. Obviously, such air cannot contain any water vapor, and the RH is set to zero (even if it would be set to $100 \%$, there would be no water vapor entrained). Figure 5 indicates that the stoichiometric flow ratio is now a much more sensitive parameter compared to the previous case.

Reasonable cell outlet temperatures can be achieved by using a relatively low stoichiometric flow ratio between $\xi=20$ and $\xi=30$. An obvious problem is that the stoichiometry has to be very accurately controlled, otherwise it is nearly impossible to control the adiabatic outlet temperature. It can be seen from Figure 5 that a change of the stoichiometric flow ratio, from, e.g., $\xi=22$ to $\xi=24$, leads to a change in the adiabatic outlet temperature by around $5{ }^{\circ} \mathrm{C}$. Therefore, it may be required to pre-heat the incoming air in such extreme climates. 


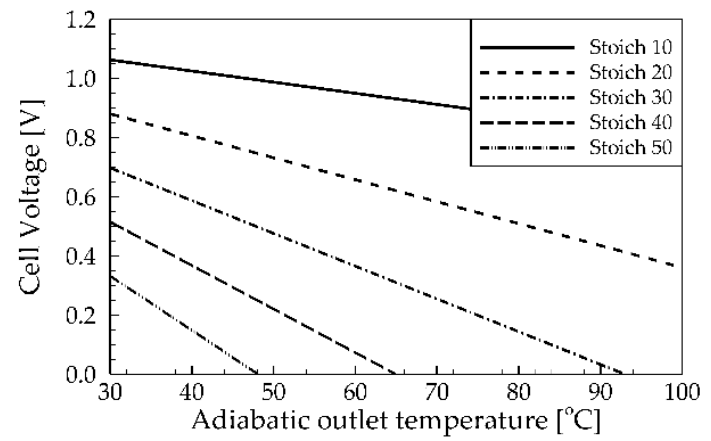

(a)

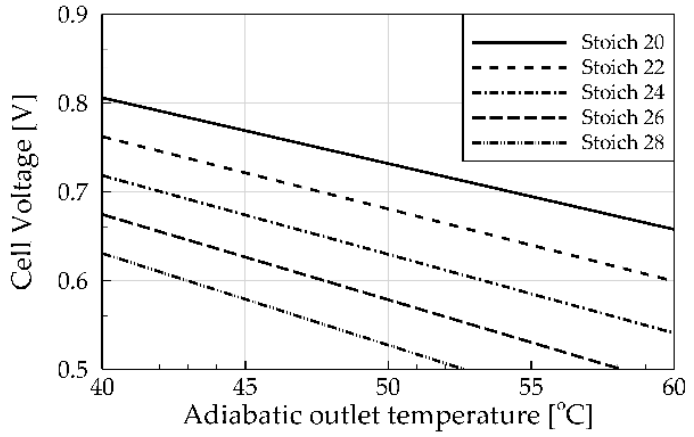

(b)

Figure 5. Dependency of the adiabatic outlet temperatures of the product stream on the operating cell voltage. The incoming conditions are a temperature of $-20{ }^{\circ} \mathrm{C}$ and a relative humidity of $0 \%$. (a) Entire voltage range, (b) close-up on the region of interest.

\subsection{Case 3: Hot and Humid Conditions}

A second extreme climate case is an ambient temperature of $40{ }^{\circ} \mathrm{C}$ and an $\mathrm{RH}$ of $100 \%$. As shown in Figure 6, in such a case, the stoichiometric flow ratio has to be chosen very high. Assuming a cell voltage of $0.7 \mathrm{~V}$, the stoichiometric flow ratio would need to be in the range of $\xi=75$ and higher to attain a reasonable adiabatic outlet temperature of $60^{\circ} \mathrm{C}$. Especially at elevated current densities, this would require a stronger blower. Thus, the blower specification is very tightly coupled to the fuel cell operating region. These diagrams clearly show that in every different climate zone, there is a different operating regime for the same hardware, which has to be carefully adjusted.

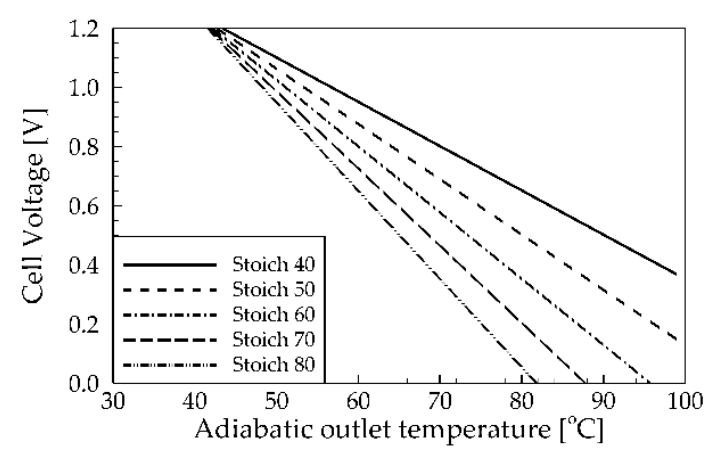

(a)

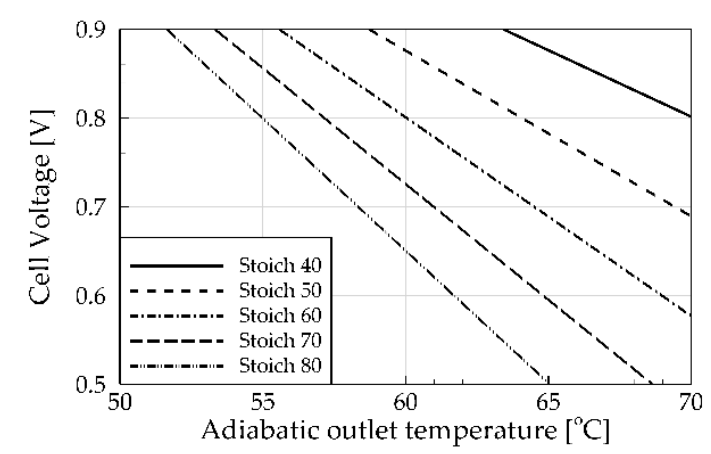

(b)

Figure 6. Dependency of the adiabatic outlet temperatures of the product stream on the operating cell voltage. The incoming conditions were a temperature of $40{ }^{\circ} \mathrm{C}$ and a relative humidity of $100 \%$.

(a) Entire voltage range, (b) close-up on the region of interest.

\subsection{Case 4: Hot and Dry Conditions}

Finally, hot and dry outside conditions shall be investigated. Figure 7 shows the diagrams for an inlet temperature of $40^{\circ} \mathrm{C}$ and an outside relative humidity of $30 \%$. While the inlet $\mathrm{RH}$ at lower temperatures has a weak effect on the ability to operate the cell, at elevated temperatures, this effect becomes larger. This is in very good accord with the operating conditions suggested by Ballard Power Systems [4]. From Figure 7, it is suggested to maybe choose a target cell voltage to $0.75 \mathrm{~V}$ in order to obtain the same adiabatic outlet temperature of $60^{\circ} \mathrm{C}$ for the same stoichiometric flow ratio of $\xi=60$.

The question of how well the membrane is hydrated under such conditions is being addressed in a computational fluid dynamics study of the same fuel cell, with surprising results that have been published separately [25]. The current work focuses on thermodynamic aspects, and it can be seen that the adiabatic outlet temperature of the reactant gases can be calculated out of knowledge of the cell voltage and the stoichiometric flow ratio. The operating temperature of these air-cooled fuel cells is 
usually adjusted by trial-end-error, and it may be concluded from the current analysis that the adiabatic outlet temperature is a suitable definition for the operating temperature of these fuel cells.

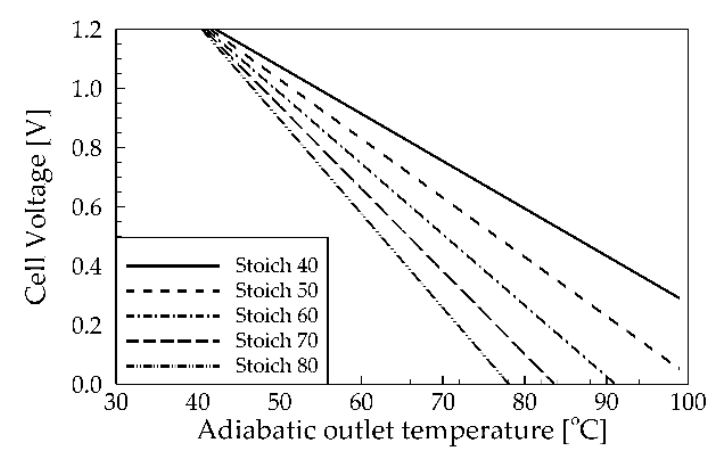

(a)

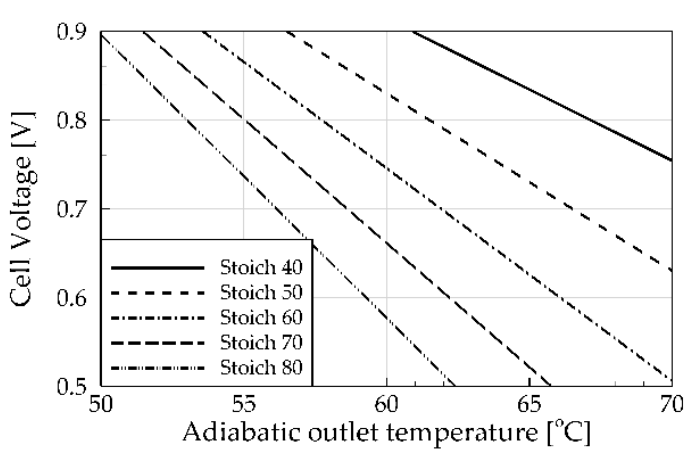

(b)

Figure 7. Dependency of the adiabatic outlet temperatures of the product stream on the operating cell voltage. The incoming conditions were a temperature of $40{ }^{\circ} \mathrm{C}$ and a relative humidity of $30 \%$.

(a) Entire voltage range, (b) close-up on the region of interest.

\section{Conclusions}

In this work, the first law of thermodynamics has been applied to an air-cooled fuel cell stack to calculate the adiabatic outlet temperature of the reactant gases in a similar way as is routinely done in combustion analysis. $V-T_{a d}$-Diagrams of the fuel cell voltage versus the adiabatic outlet temperature have been constructed that show the feasibility to operate the fuel cell in extreme climate conditions. For very cold inlet gases, the cathode stoichiometry has to be below $\xi=30$ to attain reasonable cell operating temperatures. The diagrams have also shown that it is very important to supply all fuel cell channels with the same amount of air under cold conditions. Even a mal-distribution of less than $10 \%$ can lead to a cell-to-cell variation in the adiabatic outlet temperature of $5{ }^{\circ} \mathrm{C}$, when generally, the cell-to-cell variation in temperature should be kept below $6{ }^{\circ} \mathrm{C}$ [4].

The second and third extreme climate cases were an outside temperature of $40{ }^{\circ} \mathrm{C}$ and either fully humidified or very low outside relative humidity. While the relative humidity generally plays a minor role in the construction of the diagrams, the inlet $\mathrm{RH}$ becomes more important at high outside temperatures, and this is in good agreement with the stack manufacturer's observations [4]. Stoichiometric flow ratios should be between $\xi=60$ and $\xi=80$ to keep the gas outlet temperatures within a reasonable region. Overall, the diagrams have shown that there is no inherent reason why air-cooled fuel cells cannot be operated at elevated current densities.

It is also important to realize that in the current study, it is assumed that all the waste heat is carried out by the reactant gases, i.e., that the stack is perfectly insulated. This was done for simplicity and to examine the extreme case. In real stacks, there is a certain amount of waste heat leaving the stack at the top and bottom, and the maximum temperature is often observed in the center of the stack [4].

While such a thermodynamic analysis gives valuable insight into the general feasibility to operate a fuel cell in extreme climate conditions, it does not allow a glimpse in the interior of the cell, and it did not give an answer to the question of why the limiting current density is only around $0.4 \mathrm{~A} / \mathrm{cm}^{2}$. From a thermodynamic perspective, a higher current might be attainable just by placing a larger fan behind the stack. Therefore, a computational fluid dynamics study has been conducted in order to shed light into the underlying heat and mass transfer that occurs inside such an air-cooled fuel cell [25].

\section{Patent}

Berning, T. Fuel cell assembly with a turbulence-inducing device for reduction of a temperature gradient. Patent No. WO/2019/120415, International Filing Date (17/12/2018). 
Author Contributions: Conceptualization, T.B. and S.K.K.; methodology, T.B.; formal analysis, T.B.; resources, S.K.K.; writing-original draft preparation, T.B.; writing-review and editing, T.B. and S.K.K.; project administration, T.B. and S.K.K.; funding acquisition, S.K.K. All authors have read and agreed to the published version of the manuscript.

Funding: This research was funded by EUDP, Journal number 64012-0117, and carried out in collaboration with Dantherm Power A/S and Ballard Power Systems.

Conflicts of Interest: The authors declare no conflict of interest. The funders had no role in the design of the study; in the collection, analyses, or interpretation of data; in the writing of the manuscript, or in the decision to publish the results.

\section{Nomenclature}

\begin{tabular}{|c|c|}
\hline$A$ & constant in Antoine's equation $(A=8.07131)$ \\
\hline$B$ & constant in Antoine's equation $(B=1730.63)$ \\
\hline C & constant in Antoine's equation $(C=233.426)$ \\
\hline CL & Catalyst layer \\
\hline$c_{p}$ & specific heat and constant pressure $(\mathrm{J} / \mathrm{kg}-\mathrm{K})$ \\
\hline$D$ & constant in Antoine's equation $(D=133.233)$ \\
\hline GDL & Gas diffusion layer \\
\hline$h$ & specific enthalpy $(\mathrm{J} / \mathrm{mol})$ \\
\hline$H$ & enthalpy stream $(\mathrm{W})$ \\
\hline$I$ & Fuel cell current $(\mathrm{A})$ \\
\hline$i$ & Current density $\left(\mathrm{A} / \mathrm{cm}^{2}\right)$ \\
\hline$F$ & Faraday's constant $(96,487 \mathrm{C} / \mathrm{mol})$ \\
\hline M & Molecular Weight $(\mathrm{kg} / \mathrm{mol})$ \\
\hline$\dot{n}$ & Molar flow rate (mol/s) \\
\hline PEMFC & Proton exchange membrane fuel cell \\
\hline$p$ & Pressure $(\mathrm{Pa})$ \\
\hline$Q$ & Heat Loss (W) \\
\hline RH & Relative humidity (-) \\
\hline$T$ & Temperature $\left({ }^{\circ} \mathrm{C}\right)$ \\
\hline$V$ & Voltage (V) \\
\hline$W$ & Fuel cell work (W) \\
\hline \multicolumn{2}{|c|}{ Subscripts } \\
\hline$a m b$ & ambient value \\
\hline ad & adiabatic value \\
\hline an & anode \\
\hline $\mathrm{ca}$ & cathode \\
\hline el & electric \\
\hline $\mathrm{f}$ & formation value \\
\hline $\mathrm{i}$ & denotes a species i \\
\hline in & inlet value \\
\hline out & outlet value \\
\hline prod & product \\
\hline react & reactant \\
\hline sat & saturation value \\
\hline tot & total value \\
\hline \multicolumn{2}{|c|}{ Superscripts } \\
\hline 0 & standard value \\
\hline \multicolumn{2}{|c|}{ Greek Symbols } \\
\hline$\xi$ & Stoichiometric flow ratio (Stoich) (-) \\
\hline
\end{tabular}




\section{References}

1. Sevjidsuren, G.; Uyanga, E.; Bumaa, B.; Temujin, E.; Altantsog, P.; Sangaa, D. Exergy analysis of $1.2 \mathrm{~kW}$ nexa fuel cell module. In Clean Energy for Better Environment; Aydinalp, C., Ed.; IntechOpen: London, UK, 2012.

2. Berning, T. Three-Dimensional Computational Analysis of Transport Phenomena in a PEM Fuel Cell. Ph.D. Thesis, University of Victoria, Victoria, BC, Canada, 2002.

3. Barbir, F. PEM Fuel Cells_Theory and Practice, 2nd ed.; Academic Press: Cambridge, MA, USA, 2012.

4. Ballard-Power-Systems-Inc. Mark1020 ACS ${ }^{\text {тм } F u e l ~ C e l l ~ S t a c k-P r o d u c t ~ M a n u a l ~ a n d ~ I n t e g r a t i o n ~ G u i d e ; ~}$ MAN5100192-0F; Ballard-Power-Systems-Inc.: Burnaby, BC, Canada, 2008.

5. Zhu, W.H.; Payne, R.U.; Cahela, D.R.; Tatarchuk, B.J. Uniformity analysis at MEA and stack Levels for a Nexa PEM fuel cell system. J. Power Sources 2004, 128, 231-238. [CrossRef]

6. Del Real, A.J.; Arce, A.; Bordons, C. Development and experimental validation of a PEM fuel cell dynamic model. J. Power Sources 2007, 173, 310-324. [CrossRef]

7. Larminie, L.; Dicks, A. Fuel Cell Systems Explained, 2nd ed.; Wiley: Hoboken, NJ, USA, 2003.

8. Jeong, S.U.; Cho, E.A.; Kim, H.-J.; Lim, T.-H.; Oh, I.-H.; Kim, S.H. A study on cathode structure and water transport in air-breathing PEM fuel cells. J. Power Sources 2006, 159, 1089-1094. [CrossRef]

9. Al Shakhshir, S.; Berning, T. Employing hot wire anemometry to directly measure the water balance of a commercial proton exchange membrane fuel cell stack. Int. J. Hydrog. Energy 2016, 5, 183-188. [CrossRef]

10. Adzakpa, K.P.; Ramousse, J.; Dube, Y.; Akremi, H.; Agbossou, K.; Dostie, M.; Poulin, A.; Fournier, M. Transient air cooling thermal modeling of a PEM fuel cell. J. Power Sources 2008, 179, 164-176. [CrossRef]

11. Wu, J.; Galli, S.; Lagana, I.; Pozio, A.; Monteleone, G.; Yuan, X.Z.; Martin, J.; Wang, H. An air-cooled proton exchange membrane fuel cell with combined oxidant and coolant flow. J. Power Sources 2009, 188, $199-204$. [CrossRef]

12. Sasmito, A.P.; Lum, K.W.; Birgersson, E.; Mujumdar, A.S. Computational study of forced air-convection in open-cathode polymer electrolyte fuel cell stacks. J. Power Sources 2010, 195, 5550-5563. [CrossRef]

13. Sasmito, A.P.; Birgersson, E.; Mujumdar, A.S. Numerical evaluation of various thermal management strategies for polymer electrolyte fuel cell stacks. Int. J. Hydrog. Energy 2011, 36, 12991-13007. [CrossRef]

14. Sasmito, A.P.; Birgersson, E.; Mujumdar, A.S. A novel flow reversal concept for improved thermal management in polymer electrolyte fuel cell stacks. Int. J. Therm. Sci. 2012, 54, 242-252. [CrossRef]

15. Sasmito, A.P.; Birgersson, E.; Lum, K.W.; Mujumdar, A.S. Fan selection and stack design for open-cathode polymer electrolyte fuel cell stacks. Renew. Energy 2012, 37, 325-332. [CrossRef]

16. Shahsavari, S.; Desouza, A.; Bahrami, M.; Kjeang, E. Thermal analysis of air-cooled PEM fuel cells. Int. J. Hydrog. Energy 2012, 37, 18261-18271. [CrossRef]

17. Akbari, M.; Tamayol, A.; Bahrami, M. Thermal assessment of convective heat transfer in air-cooled PEMFC stacks: An experimental study. Energy Procedia 2012, 29, 1-11. [CrossRef]

18. Meyer, Q.; Ashton, S.; Boillat, P.; Cochet, M.; Engebretsen, E.; Finegan, D.P.; Lu, X.; Bailey, J.J.; Mansro, N.; Abdulaziz, R.; et al. Effect of gas diffusion layer properties on water distribution across air-cooled, open-cathode polymer electrolyte fuel cells: A combined exsitu X-ray tomography and in-operando neutron imaging study. Electrochim. Acta 2016, 211, 478-487. [CrossRef]

19. Meyer, Q.; Ashton, S.; Jervis, R.; Finegan, D.P.; Boillat, P.; Cochet, M.; Curnick, O.; Reisch, T.; Adcock, P.; Shearing, P.R.; et al. The hydro-electro-thermal performance of air-cooled, open-cathode polymer electrolyte fuel cells: Combined localised current density, temperature and water mapping. Electrochim. Acta 2015, 180, 307-315. [CrossRef]

20. Chen, C.-Y.; Huang, K.-P.; Yan, W.-M.; Lai, M.-P.; Yang, C.-C. Development and performance diagnosis of a high power air-cooled PEMFC stack. Int. J. Hydrog. Energy 2016, 41, 11784-11793. [CrossRef]

21. Zhang, G.; Kandlikar, S.G. A critical review of cooling techniques in proton exchange membrane fuel cells. Int. J. Hydrog. Energy 2012, 37, 2412-2429. [CrossRef]

22. Flückiger, R.; Tiefenauer, A.; Ruge, M.; Aebi, C.; Wokaun, A.; Büchi, F.N. Thermal analysis and optimization of a portable, edge-air-cooled PEFC stack. J. Power Sources 2007, 172, 324-333. [CrossRef]

23. Berning, $\mathrm{T}$. The dew point temperature as a criterion for optimizing operating conditions of proton exchange membrane fuel cells. Int. J. Hydrog. Energy 2012, 37, 10265-10275. [CrossRef] 
24. Cengel, Y.; Boles, M.A. Thermodynamics-An Engineering Approach, 6th ed.; McGraw Hill: New York, NY, USA, 2007.

25. Berning, T. A Numerical investigation of heat and mass transfer in air-cooled proton exchange membrane fuel cells. In Proceedings of the ASME-JSME-KSME Joint Fluids Engineering Conference 2019, AJKFluids2019, San Francisco, CA, USA, 28 July-1 August 2019; Volume 2.

(C) 2020 by the authors. Licensee MDPI, Basel, Switzerland. This article is an open access article distributed under the terms and conditions of the Creative Commons Attribution (CC BY) license (http://creativecommons.org/licenses/by/4.0/). 